\author{
ARTIGO \\ CO https://doi.org/10.22481/praxisedu.v16i38.6001
}

\title{
THE EVALUATION AND REGULATION OF FOR-PROFIT HIGHER EDUCATION IN BRAZIL: IMPLICATIONS FOR SINAES
}

\author{
LA EVALUACIÓN Y REGULACIÓN DE LA EDUCACIÓN SUPERIOR CON FINES DE \\ LUCRO EN BRASIL: IMPLICACIONES PARA LO SINAES
}

\author{
AVALIAÇÃO E REGULAÇÃO DA EDUCAÇÃO SUPERIOR COM FINS LUCRATIVOS \\ NO BRASIL: IMPLICAÇÕES PARA O SINAES
}

\author{
Robert Evan Verhine \\ Universidade Federal da Bahia - Brasil
}

Lys Maria Vinhaes Dantas

Universidade Federal do Recôncavo da Bahia - Brasil

\begin{abstract}
Resumo: Tendo sido legalizado em 1997, o segmento com fins lucrativos recentemente passa a dominar a oferta da educação superior privada no Brasil. Dados do Censo da Educação Superior de 2017 apontavam a existência de 1.153 instituições com fins lucrativos, que respondiam por $53.6 \%$ do segmento privado e por $43,4 \%$ de todas as matrículas naquele ano. Neste trabalho, são discutidas, a partir de uma análise de dados secundários e da literatura internacional, as implicações deste segmento em três dimensões: acesso, ética e qualidade e o que isto implica para o Sistema Nacional de Avaliação da Educação Superior (SINAES). Em termos de acesso, é evidente que o aumento na oferta de vagas proporcionou maiores possibilidades para alunos, especialmente aqueles de baixa renda ou trabalhadores. Por outro lado, questões de inadimplência no pagamento das mensalidades/financiamentos e/ou uso majoritário de financiamento público, bem como o comportamento não ético de "vendas agressivas" precisam ser monitorados no Brasil, sendo observados na literatura internacional. Por fim, no País, em estudos preliminares, observou-se pouca diferença entre os resultados de IGC e CPC obtidos por instituições com e sem fins lucrativos. Propõe-se, em consequência, avaliação e regulação para a educação superior que passem a considerar, com maior cuidado: transparência institucional, o processo de vendas e seleção de candidatos, e aspectos de endividamento dos estudantes no aprimoramento do SINAES, levando em consideração esse predomínio do segmento superior com fins lucrativos, mas, mantendo sua missão de assegurar a qualidade da educação superior qualquer que seja o segmento que o oferte.
\end{abstract}

Palavras chave: Educação superior com fins lucrativos. Qualidade da educação superior privada. Aprimoramento do SINAES.

Abstract: Legalized in 1997, for-profit offerings now dominate the private higher education sector in Brazil. Data from the National Higher Education Census reveal that in 2017 there existed 1,153 forprofit institutions in Brazil, accounting for $53.6 \%$ of all private-sector higher education establishments 
and for $43.4 \%$ of all higher education enrollments in the country. Using both Brazilian data and findings from the international literature, this study discusses the for-profit phenomenon in terms of three dimensions - access, ethics and quality - and their implications for Brazil's National System of Higher Education Evaluation (SINAES). With respect to access, it is clear that for-profit offerings serve to expand higher education opportunity, especially for those who work and/or come from low-income families. On the other hand, the reliance on public student loans, the resulting student indebtedness, and a tendency to use unethical practices to recruit students and promote profits, as emphasized in the international literature, suggest that the segment requires close monitoring on a national scale. However, despite the negative consequences of the for-profit motive, preliminary analyses reveal that there is little difference between for-profits and non-profits with respect to the quality indicators (IGC and CPC) used within the context of SINAES. Based in these findings, the article concludes by arguing that the evaluation and regulation of higher education in Brazil, via the improvement of SINAES, should give greater attention to institutional transparency, student recruitment and selection, and the problem of student indebtedness. Although these suggestions are especially relevant for the for-profit sector, they also apply to higher education as a whole, since all of the country's higher education institutions must meet national standards of quality

Keywords: For-profit higher education in Brazil. Private higher education quality. SINAES

Resumen: Habiendo sido legalizado en 1997, el segmento con fines de lucro ha llegado a dominar la oferta de educación superior privada en Brasil. Los datos del Censo de Educación Superior 2017 apuntaban a 1,153 instituciones con fines de lucro, que representaban el 53.6\% del sector privado y el 43.4\% de todas las inscripciones. Este artículo analiza, a partir de un análisis de datos secundarios y literatura internacional, las implicaciones de este segmento en tres dimensiones: acceso, ética y calidad y lo que esto implica para el Sistema Nacional de Evaluación de la Educación Superior (SINAES). En términos de acceso, es evidente que la mayor disponibilidad de plazas ofrecía mayores posibilidades para los estudiantes, especialmente aquellos con bajos ingresos o trabajadores. Por otro lado, los problemas de incumplimiento en el pago de pagos mensuales / financiamiento y / o el uso mayoritario de fondos públicos, así como el comportamiento poco ético de las "ventas agresivas" deben ser monitoreados. Finalmente, en estudios preliminares en el país, hubo poca diferencia entre los resultados de IGC y CPC obtenidos por instituciones sin fines y con fines de lucro. Por lo tanto, se propone evaluar/regular la educación superior para considerar más cuidadosamente: la transparencia institucional, el proceso de venta y selección de candidatos, y los aspectos del endeudamiento de los estudiantes en la mejora del SINAES, teniendo en cuenta lo dominio del segmento con fines de lucro, pero manteniendo su misión de garantizar la calidad de la educación superior sea cual sea su oferta.

Palabras clave: Educación superior con fines de lucro. Calidad de la educación superior privada. SINAES.

\section{Introduction}

A key characteristic of higher education in Brazil is the size and significance of private institutions which are legally classified as being for-profit. Such institutions, which did not exist in Brazil before 1997, are now responsible for nearly half of the higher education institutions and student enrollment in the country. Although Brazil boasts one of the largest for-profit higher education sectors in the world, little attention has been given to this phenomenon by scholars, journalists and policy makers who deal with higher education in the country. Much has been 
said about Brazil's huge private sector, which constitutes about $85 \%$ of the country's higher education institutions and about $75 \%$ of its total higher education students, but the for-profit segment of the sector, as opposed to that classified as non-profit, has not as yet been subjected to adequate analytical or critical scrutiny. In addition, the role of Brazil's National System of Higher Education Evaluation (SINAES) in assuring that for-profit institutions meet minimum standards of higher education quality has never received serious consideration.

A differentiation between for-profit and non-profit establishments was not made in the Brazil's Higher Education Census until $2010^{1}$, and thus to date little is known about the nature and distribution of such institutions, how they function, and to what degree they offer quality education. On the other hand, academic output on for-profits is abundant on a worldwide basis, being particularly prominent in the context of the United States. Thus, in the absence of local studies $^{2}$, to better understand implications of the rise of for-profits in Brazil, it is useful to extract lessons from international experiences, analyses and critical interpretations.

The purpose of this article is to present some of the findings and conclusions emanating both from this international literature and from statistical data available in Brazil in order to discuss their potential implications and applications within the Brazilian higher education context. The article addresses three basic questions regarding for-profit institutions in Brazil: Do they expand higher education opportunity? Do they operate in an ethical manner? Do they achieve acceptable levels of educational quality?

The paper begins by briefly reviewing the development and current situation of forprofits institutions in Brazil, drawing information from national data made publicly available by the Instituto Nacional de Estudos e Pesquisas Educacionais Anísio Teixeira (INEP). It then discusses the concept and definition of for-profit higher education, indicating why the very nature of the sector raises doubts regarding its contribution and pertinence. The article subsequently reviews positive and negative aspects of the model, focusing on each of the three questions mentioned above. In the final section, the authors argue for the need for public policies that create incentives so that educational quality is promoted and assured. A list of concrete suggestions pertaining to the SINAES evaluation and regulation framework are then discussed. These suggestions take into account current legal, evaluation and regulatory

\footnotetext{
${ }^{1}$ Before 2010, the National Higher Education Census classified some private institutions as "private in the strict sense". Many scholars have assumed that this classification included only for-profit institutions, but an analysis of the data reveals that many non-profit institutions were classified in the same way.

${ }^{2}$ Scholars such as Sguissardi (2008), Oliveira (2009), Carvalho (2013) and Corbucci; Kubota; Meira (2016) provide studies of for-profit higher education in Brazil, but do not focus on the question of institutional quality and do not compare the for-profit and non-profit higher education segments.
} 
frameworks in the country and, although directed at all higher education institutions, whether public, private non-profit or private for-profit, they are specifically designed to attenuate problems inherent in the for-profit model.

\section{Background and current situation}

At one time higher education in Brazil, like that found in most regions of the world, was primarily public. However, public sector expansion has been historically restricted by limited governmental resources and the high costs associated with research-oriented establishments. As a consequence, since the 1970s Brazilian policy-makers have relied on the private sector to meet the burgeoning demand for higher education, creating incentives and a legal environment favorable to its rapid growth. This tendency was strengthened in the late 1990s, when laws were changed to permit the creation of for-profit institutions. New private establishments were rapidly created and many old ones changed from non-profit to for-profit status. As a result, by 2000 for-profit enterprises accounted for more than $10 \%$ of total higher education enrollment. The University of Phoenix, the largest and best known of the for-profits in the United States (U.S.), entered the Brazilian market in 2001, and although it withdrew from Brazil in 2006, its involvement helped create the country's largest for-profit institution and paved the way for the entry of other mega, multi-national entities (SAMPAIO, 2011).

The for-profit expansion was fueled after 2005 by several factors, including the expansion of the country's federal student loan program (FIES), the use of the Brazilian stock market to raise investment funds, the introduction of a federal program that awarded tax-exempt status to private institutions that provided a minimum number of scholarships to poor students (PROUNI), and the entry of foreign education groups seeking a more favorable business and regulatory climate than that found in most other countries (OLIVEIRA, 2009).

Many countries, particularly those in Europe, do not permit for-profit higher education institutions. In South America, only Peru allows this organizational modality on the university level. In many Asian and African countries, the for-profit model is commonplace, but it is often relegated to vocational training and other sub-university offerings and rarely constitutes a large percentage of total higher education enrollments (KINSER; LEVY, 2007). In the US, in particular, the expansion of for-profits has received in recent years a great deal of attention from the popular media, the academic community and governmental authorities on both state and national levels, but even there the sector remains very small. Between 2000 and 2010 the 
undergraduate enrollments in the for-profit sector in the U.S. increased by $329 \%$ due to the demand of students typically excluded from traditional institutions, such as those already employed, those from minority groups and/or those who had recently completed military service (WILDAVSKY, 2011). Between 2010 and 2017, however, for-profit enrollments decreased by $51 \%$, from 1.7 million students to 850 thousand, meaning that in the U.S. today the for-profit option accounts for only about $5 \%$ of total undergraduate enrollments (NCES, 2019). The reasons for the precipitous drop in enrollment will be addressed later in this article.

Thus, from an international standpoint, the size and strength of the for-profit higher education sector in Brazil is relatively unique. Data from the 2017 Higher Education Census (BRASIL, 2017a) permit an overview of key facts and tendencies. At that time, there were 1153 for-profit higher education institutions in the country, representing $47.1 \%$ of all such institutions (Fig. 01) and 53.6\% of those that were private. Within the for-profit segment, the great majority $(91.8 \%)$ were classified as colleges, rather than as university centers $(6.4 \%)$ or as full-fledged universities (1.8\%). Of the 199 universities that existed in Brazil at the time, only 21 of them were legally defined as for-profit establishments.

Fig. 01: Distribution of Higher Education institutions and enrollment per sector, Brazil, 2017

INSTITUTIONS 2017

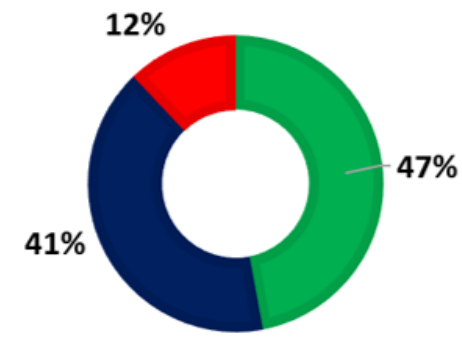

FOT-PROFIT $\square$ NON-PROFIT $\square$ PUBLIC
STUDENTS 2017

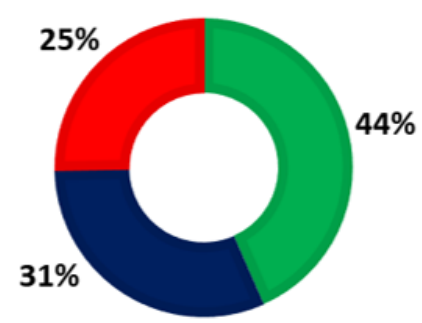

— FOT-PROFIT $\square$ NON-PROFIT $\quad$ PUBLIC

Source: INEP, Censo Educação Superior 2017

The figures pertaining to the distribution of matriculated students follow similar lines. In $2017,43.5 \%$ of all higher education enrollments were in the for-profit segment, as compared to $31.2 \%$ and $25.3 \%$ in private non-profit and public institutions, respectively (Fig. 01). Again, most the for-profit enrollment was concentrated in colleges. Among universities, the for-profit penetration was not as predominant (Fig 2.). Of total university enrollments, the for-profits accounted for $28.5 \%$, the private non-profits for $31.5 \%$, and public establishments for $39.0 \%$. 
Fig. 02: Distribution of Higher Education by University x Non-University, Brazil, 2017

UNIVERSITY

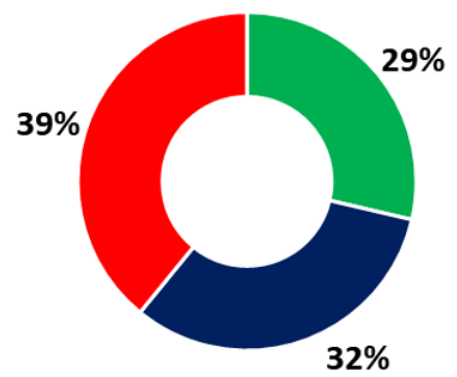

- FOT-PROFIT - NON-PROFIT $\square$ PUBLIC
NON-UNIVERSITY

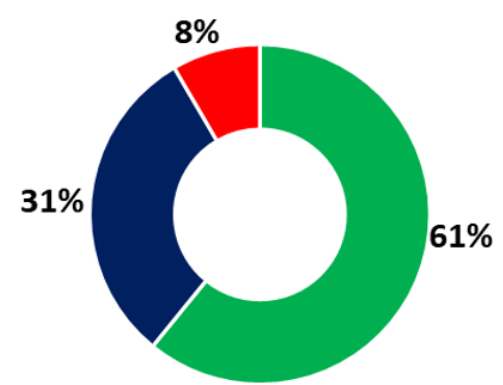

- FOT-PROFIT $\because$ NON-PROFIT $\square$ PUBLIC

Source: INEP, Censo Educação Superior 2017

Although the growth of the Brazilian for-profit sector has slowed in recent years, it remains noteworthy. Between 2010 and 2017, the number of for-profit institutions increased 15\% (from 951 to 1153), while the private non-profits decreased in reciprocal fashion, dropping from 1149 establishments to 999. Meanwhile, the size of Brazil's for-profit institutions varies greatly, ranging in 2017 from those with fewer than 50 students to others with more than 300,000 enrollees. Of the six largest higher education institutions in the country, four are forprofit enterprises.

To assess the contribution that for-profit institutions make to higher education in Brazil, it is important to note that such institutions are disproportionately concentrated in the poorer portions of the country, accounting in 2017 for more than 55\% of the establishments and $45 \%$ of the enrollments in the North, Northeast and Center-West regions combined. The corresponding figures for private non-profits were $30 \%$ and $25 \%$, respectively. A similar pattern, however, is not evident with respect to being located in a capital city rather than the interior. According to the 2017 higher education census, a little over half of both private segments, for-profits and non-profits, were situated within a state capital.

Another tendency worthy of note concerns the nature of for-profit course offerings. In 2017 the for-profits dominated the provision of distance education and technological courses, being responsible for offering $69.7 \%$ and $59.3 \%$ of these two course types, respectively.

With regard to student characteristics, the 2017 census data reveal that when compared to those who study at non-profit institutions, enrollees at for-profit establishments tended to be older, less likely to be white, and more frequently completed the secondary level at a public school. Data from the questionnaire that accompanied the 2017 National Student Achievement 
Exam (ENADE) complement this picture, indicating that those who studied at for-profit institutions, as opposed to those enrolled in non-profit establishments, were more likely to work while studying, to come from low-income families, and to have parents without a college education (BRASIL, 2017b). Thus, the Brazilian for-profits often serve those historically excluded from traditional public and private non-profit institutions, disproportionately incorporating students who are older and poorer than the country's typical college enrollee.

\section{Concepts and problematics}

The distinction between for-profit and non-profit institutions of higher education is murky. Both offer similar services, have similar organizational structures, and are subjected to similar processes of evaluation and regulation. In Brazil, few know if a given institution is forprofit or non-profit, in part because many of the for-profits used to be non-profits and have apparently remained unchanged, keeping the previous name and, in many instances, maintaining many of the same professors and administrative staff members. Also, both forprofits and non-profits tend to charge their students tuition, seek to make money and, for purposes of survival, attempt to maximize the differential between receipts and expenses. But despite these similarities, there are fundamental differences, not only in terms of legal status and fiscal obligations, but also with respect to purpose and control. The key distinction is not whether income is obtained, but rather in the use and destination of that income. In the case of the for-profits, the surplus (receipts - expenses) goes to owners and investors who can use the money they receive as they wish. Thus, those who make key decisions and formulate overall institutional policies benefit directly, in financial terms, from their input. This is not the case for the non-profits. Overall policy is determined by institutional boards composed of members who are not remunerated for their services and who therefore do not have a personal, direct financial stake in their determinations. Those who earn salaries and make operational decisions are answerable to people who do not receive salaries and can be paid only for expenses. Any surplus is required, by law, to be reinvested in the organization or in related educational pursuits. The individuals who invest in or run the institution cannot use the surplus for purposes that are personal in nature. This point is summarized in the official definition of for-profit institutions used in the U.S., which determines that they are those establishments in which "those in control receive compensation other than wages, rents or other expenses for the assumption of risk" (KINSER; LEVY, 2006, p. 111). 
Although the non-profit model suffers distortions in practice, the difference between non-profit and for-profit status can be crucial. In the international literature, it has been noted that the distinction can be understood as one between "revenues for education vs. education for revenues" or "education for the public good vs. education provided as a service to the customer" or as "education for social benefit vs. education for private gain" (HENTSCHKE; LECHUGA; TIERNEY, 2010).

These distinctions are over-simplified and often distort realities, but they are significant in that they highlight the fact that policy and decision-making incentives differ between the two organizational types and that this difference potentially relates to the issue of educational quality. Does the quest to maximize profits promote or jeopardize prospects for quality promotion in the name of academic excellence? This is a question highly debated in the international literature and the simple answer is that it depends on a variety of factors. Some scholars have argued that maximizing receipts and minimizing costs can lead to overly high tuition, unscrupulous recruiting, excessive reliance on federally funded student loans and distortions in the reporting of information about educational quality. It can also incentivize efforts to minimize teacher salaries (and therefore teacher qualification), to maximize student/professor ratios, and to keep expenditures for current costs and investment as low as possible (HALPERIN, 2014).

On the other hand, many distinguished analysts defend reliance on market forces for the formulation of higher education policy. Tooley (1999), for example, describes seven virtues of the profit motive, arguing that it creates concrete incentives for expanding and diversifying higher education, for establishing mechanisms for effective administration, for promoting quality control, for seeking to use scarce resources in an efficient manner, for giving special attention to student needs and concerns, and for attracting additional investment funds for financing educational endeavors. Kinser (2013), in similar fashion, sees the quality/profit dichotomy as fallacious, contending that "routes to profitability do not require a low-quality product" (p.2) and that "quality does not have to suffer, nor do educational expenditures have to be less, in order for excess revenue to be generated" (p.3). It can be concluded that the forprofit model embodies aspects that can be considered both positive and negative. In this respect, it is useful to consider concrete findings, reported in the international literature, as to how forprofits behave and perform in actual practice, especially with respect to the three questions mentioned above, as to whether for-profit higher education (1) promotes higher education 
opportunity, (2) operates in an ethical manner, and (3) provides a level of education that meets recognized quality standards. Each of these three is addressed below.

\section{For-profits and educational opportunities}

It is generally agreed by specialists that for-profit higher education has significantly contributed to higher education opportunity in many countries by substantially increasing the number of student slots available in colleges and universities. In Brazil, the for-profit sector, which was non-existent in 1997, now incorporates more than 3 million students. In the U.S., the number of for-profit students increased four-fold between 2000 and 2010, expanding its share of total higher education enrollments from $3 \%$ to $9 \%$ in that period. For-profit education has played an important part in higher education expansion in many other countries as well, including Malaysia, China, Ukraine, South Africa and the Philippines, among others (KINSER; LEVY, 2006).

Most concur that without the participation of for-profit institutions, many slots currently available would not exist, since neither the public sector nor the private non-profit segment would have filled the void (BENNETT; LUCCHESI; VEDDER, 2010). In all regions of the world, the offering of public higher education has been severely restricted by rising costs and limited public funds. Governments have been increasingly faced with rising debt, uncooperative tax payers, and the need to address social problems in a multiplicity of different fields. Brazil is one of the few countries in world to significantly expand public higher education in the past decade, but even so the sector still reaches only about $6 \%$ of those aged 18 to 24 , its theoretical cohort of focus (VERHINE; DANTAS, 2018). In a similar vein, with rising costs and the absence of the profit incentive, the private, non-profit higher education segment has stagnated with respect to growth, not only in Brazil but also in other countries. In this respect, some scholars have made reference to what they call the "Brazilian Effect", whereby for-profit institutions "rush in and fill the gap" created because public and private non-profit higher education "cannot keep pace with growing public demand for access and programs" (DOUGLASS, 2012, p. 1).

Most observers also agree that the expansion of for-profit higher education has promoted a greater diversity of higher education offerings (BENNETT; LUCCHESI; VEDDER, 2010). Making a profit is related to meeting specific student demands, and many such students demand places in an ever-changing job market, where new occupations are being 
constantly created in order to deal with new technological demands and customer tastes. Unhampered by past academic traditions and ritual, for-profit institutions can easily adapt to (and profit from) the demands of job markets that are in constant flux. As an example of the institutional flexibility of the for-profit segment, one can point to its dominance with respect to the provision of courses via distance education. In the U.S., $60 \%$ of for-profit education is administered from a distance (USDE, 2019). For Brazil, the corresponding percentage is $19.6 \%$, much higher than for non-profit (8.1\%) and public (5.2\%) institutions (BRASIL 2017a).

Another aspect that illustrates the contribution of the for-profit segment to higher education opportunity is the fact that for-profit institutions tend to disproportionately enroll "non-traditional" students who otherwise would not go to college. Studies consistently show that those who study in for-profit establishments, when compared to those enrolled in traditional institutions, are more likely to be people who are older, poorer, fully employed and a member of a minority group that is subjected to social discrimination (CAPSEE, 2019). As indicated in the section above, this tendency is evidenced in Brazil by national census data, although it does not appear to be as strong as in the US, where a large percentage of the student demand for forprofit education comes from former members of the armed services.

Thus, the for-profit segment typically receives high marks with respect to the first research question. But these high marks can be easily undermined if the expansion of the education provided is due to unethical recruiting practices and if the education provided is of poor quality. These two "ifs" are addressed in discussing the remaining two questions that undergird this study.

\section{For-profits and organizational ethics}

The question of for-profit higher education ethics is viewed as being highly problematical by much of the international literature and, especially, by the international popular media. Of course, institutions that act ethically do not receive attention or generate provocative articles. Also, institutions of all types must deal with ethical issues, depending on the degree of social responsibility exhibited by those who manage them. Nevertheless, a quick google search of for-profit education generates a huge number of hits that pertain to serious lapses in ethical behavior within the for-profit sector. In the context of the U.S., lawsuits by unhappy students and disciplinary action taken by states and the federal government against participants in the for-profit industry are commonplace. It appears that the most prevalent 
ethical problem concerns the recruiting of new students. For-profits depend on economies of scale to maximize surplus and therefore seek to attract as many students as possible. This often leads to aggressive recruiting whereby promises made to students regarding their likelihood of graduating and getting a good job are greatly exaggerated. The tendency to pay recruiters in accordance with the number of students that they enroll often aggravates the problem, leading to high-pressure sales techniques and false assurances. A U.S. Senate investigation was able to graphically detail the fraudulent, unsavory behavior of many for-profit recruiters by sending its staff members to for-profit recruiting offices pretending to be potential students. In many cases, the bogus students indicated that they were unable to read and write, but were still able to enroll (and pay tuition), with the help of recruiters who filled out the necessary documents for them. The resulting Senate report also revealed that for-profit institutions commonly spend more on advertising and recruiting than they do on activities pertaining to learning and instruction (U.S. SENATE, 2012).

In many countries, private institutions are able to benefit from government-sponsored student loan programs. Thus, by attracting more students, institutions can benefit from student loans that provide them money with little or no risk. Many students fail to complete their studies, do not obtain the good jobs they expect, and are saddled with huge debt obligations. Research reveals that in the U.S. students who attend for-profit institutions are those most likely to default on their loans, resulting in huge costs that must be absorbed by the government and, ultimately, by the tax payer. Thus, according to a recent book by A.J. Angula (2016), for-profit institutions in the U.S. have "stiffed students, taxpayers and the American dream." A second book, this one by David Halperin (2014), makes a similar accusation, arguing that they "scam taxpayers and ruin student lives". The above-mentioned U.S. Senate investigation came to a similar conclusion, contending that for-profits fail to ensure student success and therefore do not adequately safeguard the loan investments made by the federal government (U.S. SENATE, 2012). It is mainly because of publications such as these that, as already noted, total enrollment in the U.S. for the for-profit segment decreased by more than 50\% between 2010 and 2017.

There is no concrete evidence that these ethical abuses are widespread in Brazil. There are reasons to believe that profit and non-profits in Brazil are much more alike than in the U.S. In the U.S., the two private subsectors tend to be strongly differentiated, with different origins, goals, and evaluation/regulatory systems. In Brazil, on the other hand, for-profit and non-profit institutions are evaluated and regulated in the same way. All of them must meet the same quality standards, as established by the SINAES framework. In addition, unlike in the U.S., many for- 
profits use to be non-profits and continue to function as they did before. Also, the mobility of professors between the for-profit and non-profit segments is often substantial, which probably contributes to the development and maintenance of academic climates that are similar in the two organizational types.

\section{For-profits and educational quality}

If the above hypothesis regarding the similarity between for-profit and non-profit higher education institutions is correct, one should expect a convergence with respect to their levels of educational quality. In this respect, it should be noted that international findings regarding the quality of for-profit institutions are mixed. On the one hand, a number of scholars paint a positive picture, arguing that for-profit institutions often seek to raise revenues by offering a product of high quality in order to attract students (and their tuition fees) and to burnish their reputation and image within the surrounding community. In Brazil, many forprofits receive good grades from SINAES, and in the U.S, some offer degrees, including the Ph.D., which are highly reputable. On the other hand, a large amount of literature contends that the profit motive is often highly detrimental to quality. Many institutions consider profits as being more important than serving the public good and therefore, in the name of greater efficiency, seek to cut costs by paying low wages, hiring part-time professors, maximizing student/professor rations, and skimping on operational and investment expenses (ANGULO, 2016; HALPERIN, 2014). A variety of studies have argued that for-profit institutions are often plagued by high student dropout rates and low labor market returns for those who graduate (HENTSCHKE; LECHUGA; TIERNEY, 2010). The allegation of low quality has led to the opening of many judicial processes in the U.S. against for-profit institutions by disgruntled students. At the same time, the U.S. Department of Education has officially denounced the agency that accredits most for-profits in that country, for using lax and ineffective criteria to monitor the non-profit sector (HALPERIN, 2016).

There are many definitions of higher educational quality. For the purpose of regulating higher education in Brazil, quality is understood as involving a combination of factors pertaining to faculty, pedagogical process, physical infrastructure and student learning. These elements are operationalized by way of a multi-variable quality score for each program and for 
each institution, designated respectively via the acronyms CPC and IGC. ${ }^{3}$ Each is measured on a five-point scale in accordance with the normal curve. Analyses of the CPC and IGC data over time reveal that the average grades for non-profit and for-profit institutions are essentially identical. For example, the data for 2017 that pertain to universities indicate that the average CPC grades for non-profit and for-profit institutions were 2.82 and 2.79 , respectively. For all institutions, the corresponding averages were 2.71 and 2.65 (Fig. 03).

Fig. 03: Average global and university CPC grades by higher education sector, Brazil, 2017

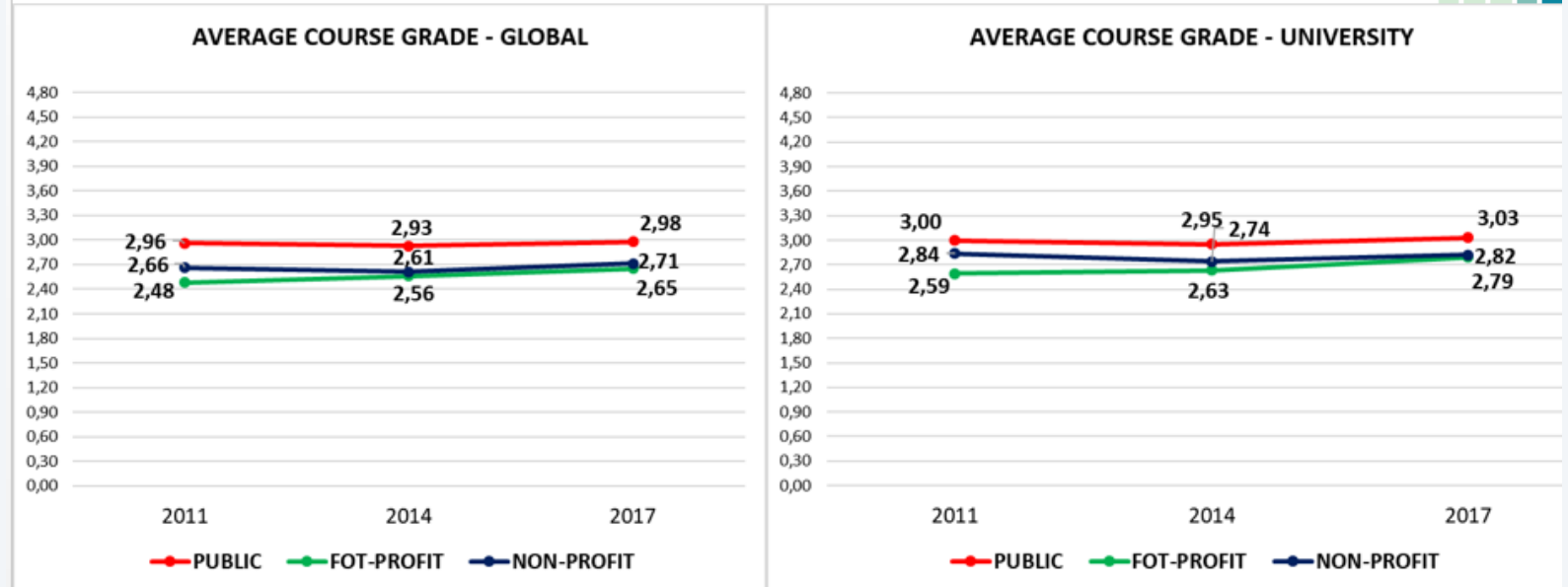

Source: INEP, Censo Educação Superior 2017

With respect to IGC results, the tendencies for 2017 were similar, with non-profit versus for-profit grade averages of $2.86 \times 2.79$ for universities and $2.53 \times 2.45$ for all institutions (Fig. 04).

Fig. 04: Average global and university IGC grades by higher education sector, Brazil, 2017

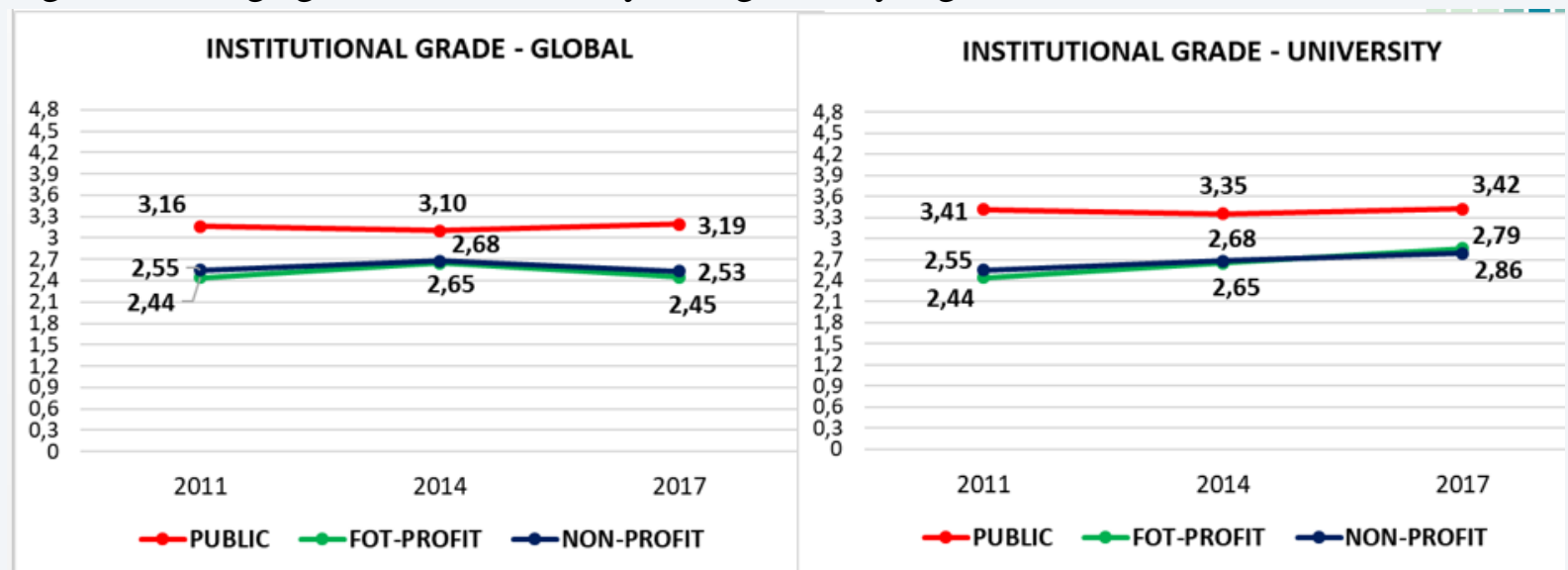

Source: INEP, Censo Educação Superior 2017

\footnotetext{
${ }^{3}$ The CPC (Preliminary Course Grade) is calculated for each undergraduate course in the country based on student performance on the ENADE test, the qualification and work regime of the professor, and the evaluation by students of the quality of course teaching and of its physical infrastructure. The IGC (General Institutional Grade) is the weighted average of the all CPCs for a given institution.
} 
The fact that the non-profit versus the for-profit differential is so small is noteworthy, since the non-profit group includes prestigious denominational institutions and tends to serve students with relatively more favorable socio-economic backgrounds. Regression analysis for both IGC and CPC scores indicates that the observed difference between the non-profits and the for-profits disappears when student characteristics are controlled for. Since for-profit students are more likely to come from low-income families, have parents without a college education, and have attended a public secondary school, it is likely that these factors, and not the quality of the course taken, account for the for-profits' slightly lower quality scores. Thus, the available evidence supports the hypothesis of quality correspondence mentioned above. These findings, however, are still preliminary. It is obvious that more sophisticated analyses are required to fully understand the relationship between non-profit/for-profit status and educational quality.

\section{Implications for evaluation and regulation in Brazil}

Introduced by federal law in 2004, Brazil's system for evaluating higher education SINAES - is widely considered to be one of the most sophisticated large-scale evaluation systems in the world, requiring self-evaluation, student testing via ENADE (a nationwide and standardized exam), visits by external evaluators to courses and institutions, and the use of composite indicators, such the IGC and CPC mentioned above. The system does not differentiate evaluation criteria or mechanisms by sector (public x private).

Consequently, SINAES has received criticism from private sector representatives from both for-profit and non-profit segments regarding unfair treatment. Their complaints include that the national exam discriminates against private institutions, since most cater to low income students who suffer testing difficulties which are independent from the quality of their program of study. Thus, organized private sector interest groups have attempted to overturn (or at least significantly alter) the SINAES law ever since it was passed, but they have not been successful so far.

However, given the problems identified worldwide with respect to the for-profit sector, it is useful to contemplate additional regulatory dictates. As stated in the afore-mentioned report produced by the US Senate, regulations must "align the incentives of for-profit colleges so that the colleges succeed financially when students succeed" (U.S. SENATE, 2012, p.19). In Brazil, 
therefore, new rules should be considered that address the problems related to the for-profit sector that are highlighted by the international literature. These problems are not exclusive to for-profit institutions and so the new rules suggested below should apply to private non-profit institutions as well. These rules pertain to recruiting, transparency and student indebtedness.

\section{Recruiting}

Student recruiting practices have received little attention from the higher education evaluation and regulation authorities in Brazil. Based on the experience of other countries, two national rules would appear to be appropriate. First of all, as in the US, recruiter payment based on the number of students recruited should not be allowed. This rule would mitigate against the incentive to engage in aggressive and/or misleading selling practices. Secondly, no institution should be allowed to spend more on advertising and recruiting than it does on its core educational services. In this respect, the use of federal funds from FIES or other sources for advertising and marketing should be prohibited.

\section{Transparency}

Students, potential students and their parents must have accurate, relevant information in order to choose their preferred institution and field of study. Institutions should be required to include on their webpage reliable data pertaining to approval and completion rates and student labor market success, including the percentage of graduates obtaining gainful employment after graduation and their salary level. This requirement would make it necessary for institutions to collect information on student flows and the labor market success of graduates. Few institutions in either the public or private sector effectively collect such information today, but if mandated, such information can easily be obtained through institutionalized systems of monitoring and accompaniment. A related recommendation would be to create an online student complaint clearinghouse, managed by MEC, for the collection and referral of student complaints to appropriate overseeing agencies, organizations and government sectors.

Student indebtedness 
Brazil should follow the lead of the U.S. to try to avoid excessive dependence of institution and students on FIES and other loan programs. In the US, institutions cannot receive more $90 \%$ of their income from public sources. Additionally, to be eligible for the receipt of student loan money, institutions must keep their average student default rates below $30 \%$. Also, their graduates, on average, must be gainfully employed, so that after graduation their average annual debt payment is not greater than $12 \%$ of their annual income. These percentages need not be the same for Brazil, but rules pertaining to default rates and income to debt ratios that must be met in order to have access to public funding (such as FIES) would appear to be highly appropriate within the Brazilian context.

Improvement of SINAES

Finally, in closing, it is important to consider how the existing SINAES framework can be improved. It has functioned now for 15 years and has represented an important ingredient in higher education quality assurance. It can be commended for emphasizing student learning as the most important aspect of higher education and for recognizing the value of professor qualification, professor work regime, and student satisfaction with respect to pedagogic organization and physical infrastructure. However, a number of conceptual and operational aspects can be improved. Space does not allow for an adequate discussion of this issue, but included among appropriate alterations would be (1) to make present criteria, as expressed in the instruments used for the course and institutional visits, more demanding, (2) to give greater attention to the quality of student services regarding academic assistance and job placement, (3) to increase the relevance of the ENADE test by giving much greater emphasis to general academic competencies, such as critical thinking, analytical reasoning and problem solving, and (4) to adjust the ingredients of key indicators, such as the CPC and IGC, so that they respect the different types, goals and geographic contexts of Brazil's higher education institutions.

\section{REFERENCES}

ANGULO, A.J. Diploma Mills, Baltimore: Johns Hopkins, 2016.

BENNETT, D.L.; LUCCHESI, A.R.; VEDDER, R.K. For-profit higher education: growth, innovation and regulation. Columbus, $\mathrm{OH}$ : Center for College Affordability and Productivity, 2010. 
BRASIL. Ministério da Educação. Instituto Nacional de Estudos e Pesquisas Educacionais. Censo da Educação Superior 2016. Brasília: INEP, 2017a

BRASIL. Ministério da Educação. Instituto Nacional de Estudos e Pesquisas Educacionais. Educação superior/indicadores/cpc 2017. Brasília: INEP, 2017b

BRASIL. Ministério da Educação. Instituto Nacional de Estudos e Pesquisas Educacionais. Educação superior/indicadores/igc 2017. Brasília: INEP, 2017c

CAPSEE, Center for Analysis of Postsecondary Education and Employment. For profit colleges by the numbers, 2019. At: https://capseecenter.org/research/by-the-numbers/forprofit-college-infographic/ Consulted 21/08/2019.

CARVALHO, C.H.A. A mercantilização da educação brasileira e as estratégias de mercado das instituições lucrativas. Revista Brasileira de Educação, v. 18; n. 53, p. 761-776, 2013.

CORBUCCI, P.R.; KUBATA, L.C.; MEIRA, A,P.B. Reconfiguração estrutural ou concentração de mercado superior privada no Brasil. Radar, n. 46, ago., p. 39-45, 2016.

DOUGLASS, J.A. Money, politics and the rise of for-profit higher education in the U.S. Research and occasional paper, Center for Studies of Higher Education, University of California, Berkeley, 2012.

HALPERIN, D. Department of Education staff moves to dump for-profit college accreditor. Blog, 06/15/2016. At: https://www.linkedin.com/pulse/dept-education-staffmoves-dump-for-profit-college-david-halperin Consulted 08/30/2016.

HALPERIN, D. Stealing America's Future: How For-Profit Colleges Scam Taxpayers and Ruin Students' Lives. Washington D.C.: Republic Report, 2014.

HENTSCHKE, G.C.; LECHUGA, V.M.; TIERNEY, W.G. For-Profit Colleges and Universities: Their Markets, Regulation, Performance, and Place in Higher Education. Herndon VA: Stylus, 2010.

KINSER, K. The quality-profit assumption. International Higher Education, n. 71, Spring, p. 12-13, 2013.

KINSER; K.; LEVY, D.C. For-profit higher education: U.S. tendencies, international echoes. In: J.F, FORREST, J.F.; ALTBACH, P.G (eds.), International handbook of higher education. New York, NY: Springer, p. 107-119, 2007.

OLIVEIRA, R.O. A transformação da educação em mercadoria no Brasil. Educação e Sociedade, 30 (108), p. 739-760, 2009.

SAMPAIO, H. O setor privado de ensino superior no Brasil: continuidades e transformações. Revista Ensino Superior Unicamp, v.4, p. 28-43, 2011.

TOOLEY, J. Should the profit sector profit from education? Educational Notes. No. 31. London: Liberatarian Alliance, 1999. 
USDE. United States Department of Education. The Condition of Education 2019. Washington D.C.: National Center for Education Statistics, 2019. At: https://nces.ed.gov/pubs2019/2019144.pdf Consulted 21/08/2019

UNITED STATES SENATE. For profit higher education: report of the Health, Education, Labor and Pensions Committee. Washington D.C.: U.S. Senate, 2012.

VERHINE, R.E.; DANTAS, L.V. Brazil: problematics of the tripartite federal framework. In: CARNOY, M.; FROUMIN, I.; LESHUKOV O.; MARGINSON, S., Higher Education in Federal Countries: A Comparative Study, New York: Sage, 2018, p. 212-257

VERHINE, R.E. O novo alfabeto do SINAES: reflexões sobre o IDD, CPC e IGC. In: DALBEN, A., DINIZ, L. and SANTOS, L. (eds.). Convergências e tensões no campo da formação e do trabalho docente. Belo Horizonte: Autêntica, 2010.

WILDAVSKY, B. The great brain drain: how global universities are reshaping the world. Princeton, NJ: Princeton University Press, 2010.

Acknowledgments: Initial research conducted for this article was undertaken by Robert Verhine in 2016 while serving as a Visiting Scholar at the Lemann Center for Educational Entrepreneurship and Innovation at Stanford University.

\section{SOBRE OS AUTORES:}

\section{Robert Evan Verhine}

Doutor em Educação pela Universitat Hamburg (Alemanha). Professor Titular aposentado da Universidade Federal da Bahia. Grupo Política e Gestão em Educação. E-mail: rverhine@gmail.com

iD http://orcid.org/0000-0002-5157-3680

\section{Lys Maria Vinhaes Dantas}

Doutora em Educação pela Universidade Federal da Bahia; Professora da Universidade Federal do Recôncavo da Bahia; Grupo Organizações, Gestão e Políticas Públicas. E-mail: lys@ufrb.edu.br

(iD http://orcid.org/0000-0001-8225-2321 